\title{
Social Capital, Information Flows, and Income Creation in Rural Canada: A Cross-Community Analysis ${ }^{1}$
}

\author{
M. Geepu Nah Tiepoh* \\ Department of Economics \\ Concordia University \\ Bill Reimer \\ Department of Sociology \\ Concordia University
}

Published as:

Tiepoh, M. Geepu Nah and Bill Reimer (2004) Social capital, information flows, and income creation in rural Canada: a cross-community analysis, Journal of Socio-Economics 33:427-448.

The definitive version is available at www.elsevier.com.

\begin{abstract}
We propose that (i) social capacity, defined as the ability of people to organize and use their social capital, does influence their level of income, and that (ii) this is because social capital use facilitates the flow of income-related knowledge and information between economic agents. Tests of these propositions based on a framework classifying social capital as a productive asset embedded in four types of social relations, and using data on household and community social capital for rural Canada, revealed some supportive evidence.
\end{abstract}

Keywords: Social Capital; Income; Information; Rural; Development

*Correspondence: M. Geepu Nah Tiepoh, Department of Economics, ER 100-28, Concordia University, Montreal, Quebec, Canada H3G 1M8 Tel: (514)848-2424, ext. 3930. Fax: (514)848-4536, Email: geepunah@alcor.concordia.ca

${ }^{1}$ This paper has used data generated from the New Rural Economy Project (NRE) of the Canadian Rural Revitalization Foundation (CRRF). We greatly thank all NRE researchers and the many rural people who participated in the project for their contributions. Primary financial support for the project was provided by the Social Science and Humanities Research Council under their Strategic Grant Programme on Social Cohesion. 


\section{Social Capital, Information Flows, and Income Creation in Rural Canada: A Cross-Community Analysis}

\section{INTRODUCTION}

Understanding the crucial factors that influence the income levels of rural communities may hold the key to effective rural development policy-making. Various theoretical models have emerged in the growth literature aiming to test factors, such as differences in technical progress, public spending, macroeconomic stability and initial endowments of physical and human capital, as explanations for cross-country and interregional variations in the level and growth rate of income (Barro and Sala-I-Martin, 1995; Datt and Ravallion, 1998). The basic frameworks of such models have also been applied to analyzing the role of social capital and other non-economic factors in economic growth. It has been suggested and empirically confirmed that social capital, viewed as a form of productive asset and resource embedded in social structures and relations, does facilitate economic actions and performance (Helliwell and Putnam, 1995; Knack and Keefer, 1997; Temple 1998; Temple and Johnson, 1998; Whiteley 2000).

Interest in the role of social capital in economic development was rekindled by the work of Putnam (1993) explaining why the level of income in the North of Italy was higher than that in the South. His research found that variations in per capita income between the two regions were explained by differences in social structure, with horizontal structures common in the North and hierarchical or 
vertical forms in the South. In subsequent research Amin (1994) showed that the structure of the network of social relationships within which firms operated in Italy similarly affected their performance. Thus the evidence suggests that social capital, viewed as networks of social relationships, has an impact on economic performance which, as found in some cases, is at least as strong as that of human capital or education (Whiteley, 2000). It is also argued that the more developed these social networks (i.e. the denser and stronger their component relationships), the greater is the stock of social capital (Barr, 2000).

Granted that social capital of the form described above contributes to economic performance, what are the specific mechanisms through which it might influence such performance? Following Barr (2000), it can be argued that social capital in the form of networks of social relationships embedded within bounded institutional or diffused community structures, influences economic performance partly because such networks facilitate the flow of technical information and knowledge that helps reduce economic transaction costs as well as serve as crucial input in the production process. The suggestion that networks of social relationships within institutions and communities facilitate the flow of vital information and knowledge has long been argued by various sociologists including Coleman et al. (1966) and Granovetter (1973). For instance, according to Coleman et al. (1966), the more deeply integrated a physician was in her local medical community, that is, the more links and contacts she was involved in, the 
earlier she got to know about and use a new drug (Barr, 2000). Granovetter (1973; 1995) found that strong networks of relationships allowed job seekers to obtain vital information on job opportunities. Fernandez, Castilla and Moore (2000) found that employers who hired new workers via employee referrals gained economic returns in the form of better hiring outcomes. Thus a common theme in the growing literature on social capital suggests that it contributes to achieving valued economic outcomes because of its ability to facilitate technical information and knowledge flows within the economy.

Our objective in this paper is to provide a theoretical and empirical analysis of the extent to which social capital influences income levels in rural Canada. Two interdependent research questions are explored: "How important is the role of social capital in generating income in the communities of rural Canada?" and "What is the extent to which information and knowledge flows, via social relationships and networks in these communities, facilitate such a role?" Section 2 defines our approach to social capital within a broader social capacity framework, in which different types of social relations and processes embedded in community institutions and organizations are viewed as generating social capacity for achieving valued economic outcomes. Section 3 specifies an appropriate empirical framework in which our two research questions are formulated and modeled. In section 4 we estimate the models formulated in the previous section using crosssectional data on household and community social capital from the New Rural 
Economy (NRE) project of the Canadian Rural Revitalization Foundation (CRRF). The empirical results are analyzed in section 5 . This is followed by a section summarizing the main conclusions and policy implications.

\section{SOCIAL CAPITAL, INFORMATION, AND INCOME}

Following Coleman (1988), social capital can be defined in terms of its nature and function. It is made up of a variety of different entities all consisting of some feature of social structures. Unlike human and physical capital, which are lodged either in individual actors themselves or in physical implements of production, social capital inheres in the structure of social relations between actors and among actors. It is exemplified in various forms such as obligations and expectations, information channels, and social norms. Social structure, itself, may exist in relatively bounded and discrete forms, such as organizations, or in more diffuse forms, such as extended families and communities or in other loosely bounded social systems (Sandefur et al., 1999). However, as Sandefur and Laumann (1998) explained, social structure always consists of relationships in which social capital is embedded. Furthermore, Bebbington and Perreault (1999) and Reimer (2002a) have argued that social capital can also be treated as both a stock of assets (networks, institutions) that can be drawn upon for productive ends and a flow of assets (social participation, collective action) aimed at reinforcing existing social capital. 
In addition to being an aspect of social structure, social capital can also be defined by its function in terms of its ability to facilitate certain actions of actors within the structure. Thus, as Bebbington and Perreault (1999, p. 4) argued, "the specific emphasis is always on the role of social capital in fostering efficiency (by reducing transaction costs) and controlling defection and dishonesty (by fostering a mix of norms, sanctions, and fear of reprisal)." According to Putnam (1995), whereas physical and human capital are tools and training that enhance individual productivity, social capital are features of social organization such as networks, norms, and social trust that facilitate coordination and cooperation for mutual benefit. Sandefur and Laumann (1998) also argued that social capital, like other types of capital, has a productive capacity that can extend beyond generating economic returns to providing useful benefits for attaining any specified types of goals. Social capital's productive capacity results from its informational, influence and control, social solidarity, and other types of benefits which can be utilized to facilitate the achievement of specified goals. Coleman (1994) also described social capital as any aspect of informal and formal social organization that constitutes a productive resource for one or more actors.

Based on the above definition of social capital, and following an approach to human relations rooted in anthropological literature (Fiske, 1991) and elaborated by Reimer (2002a), we develop the following three-featured analytical framework that explains the nature and role of social capital. First, our framework 
classifies social capital as a feature of four fundamental modes of social relations: market relations, bureaucratic relations, associative relations, and communal relations. Market relations are those based on the exchange of goods and services within a relatively free and information-rich context, as governed by the classical economic assumptions of demand and supply, price adjustment, free information flow, and factor and product mobility. Market-based relationships tend to be short-term and limited for the purpose of exchange, and they require access to tradable goods or services, adequate information about markets and prices, good negotiation skills, and high level of mobility. Strong market-based social capital contributes to income creation and distribution by enhancing market efficiency.

Bureaucratic relations are the type of impersonal and formal relationships based on a rationalized division of labor, the structuring of authority and positions through formal principles and rules, and the explicit or implicit allocation of rights and entitlements based on assigned positions and statuses. Such relations are often associated with state or corporate structures organized as hierarchies, where authority is delegated vertically from central to subordinate positions, but they may also take a horizontal form, organized in a rational manner. Facility with bureaucratic-based social capital has become increasingly important over the last 50 years as states and corporate organizations have come to dominate economic and social life. Knowing how to find a job, access transfer payments, expand trade, or avoid taxes requires familiarity with bureaucratic modes of relating and 
negotiation that are significantly different from those reflected in market relations. Entrepreneurial frustration with 'red tape' and the uncertainty of policy attest to these differences while acknowledging the importance of bureaucratic relations for income creation and distribution.

Associative relations are those primarily based on shared interests and characterized by focused objectives, informal structures, and short-term lifespan. They are most often found in voluntary associations, clubs, and informal groups where people meet to play, learn, share, or protest. These are the types of social relations most often considered in the empirical research on social capital (Putnam, 1995; Knack and Keefer, 1997). Social capital based on associative relations contributes to income by transferring information, building trust, and enabling low-cost evaluation of prospective partners or clients. Our field-based research also provides many examples whereby informal social groups form the basis for small-scale enterprises and the eventual development of market relations.

Finally, communal relations are those founded on strongly shared identity, in which rights and obligations of members are largely determined by custom, and distribution of goods and services is done according to need rather than status or ability to pay. These are most likely to be found within family, clan, or close friendship networks. They provide sources of income through remittances, preferred transfers, jobs, and special entitlements. Social capital based on communal relations also provides an important form of risk reduction, especially 
in marginal economies. Once again, our research provides a number of examples where communal-based social capital acts as an incubator for market-based relations and entrepreneurial activity.

All four types of social capital are found in most circumstances, but the particular balance and relationships between them will vary. In some contexts they reinforce one another as illustrated by the merging of market and bureaucratic relations within the modern corporation. In other contexts, they create contradictions that undermine economic objectives. Communal or associative types of relations, for example, are often cited as the basis for market inefficiencies since they tend to increase transaction costs between groups or members. Similarly, market-based social relations are often viewed with suspicion by friendship circles or voluntary groups, since they undermine the collective interests of the group.

Economic fortunes are also affected by the relative strength of the various types of social capital and an individuals' ability to function within them. In our work on rural development, for example, we argue that the contemporary predominance of market and bureaucratic relations places rural communities at a disadvantage since their traditional strengths lie with associative and communalbased social capital. In many of our field sites, the traditional allocation of rights and resources through patronage or need (reflections of associative and communal relations) have given way to allocation by general regulation or market 
performance (reflections of bureaucratic and market relations). In the process, those who are skilled in the latter types of relations enjoy a significant advantage, resulting in dramatic shifts in the status and power relations within those sites.

In the second feature of the framework we argue that each of the abovementioned four modes of social relations resides and operates within relatively bounded organizational/institutional structures and diffused social systems (e.g. extended families) in rural communities. Thus, such community-based institutional structures and social systems, by virtue of being manifestations of these highly coordinated social relationships, are the key repositories of social capital. For example, a community that has a high concentration of market-based organizations is likely to have high levels of market-based social capital. In terms of this feature, social capital is viewed in terms of its availability within institutional and community-level forms rather than how and for what it is used. This is a very important difference, since the availability of social capital within community institutions and social systems is not necessarily equivalent to its $u s e .{ }^{1}$

Rural communities may have access to social capital within their institutions and organizations, which they do not use. Indeed, as one anonymous reviewer pointed out, rural communities in decline may have a stock of social capital that is no longer used for productive purposes.

\footnotetext{
${ }^{1}$ The availability of social capital refers to its mere presence and potential accessibility within community organizations, whereas its use relates to how and the extent to which it is actually used.
} 
The final feature of the framework relates to the role of social capital in economic development. In line with the current body of theoretical and empirical literature, we argue that certain kinds of social capital are assets and resources that can be organized and used through appropriate social structures and processes to produce valued economic outcomes for rural communities. An important aspect of this perspective is social capacity, which refers to the ability of rural people to organize and use their social capital and other assets through various social structures and processes to achieve valued economic objectives (Reimer, 2002a). From this point of view, social capital becomes analogous to a factor input, like labour, physical or human capital, which must be combined with other factors of production using a particular production technology to produce a valued economic outcome. ${ }^{2}$ An additional feature of the framework is that in the process of combining and using these social capital assets, rural communities are able to generate certain valued outputs, such as social and political inclusion and social cohesion, which can also serve as new forms of social capital. Thus social capital itself can become an output of social processes. However, the focus of our analysis is not on these kinds of social outputs but on social capital as an input that can be used in productive ways.

\footnotetext{
${ }^{2}$ In the neoclassical production function, the economy's output is produced by combining various factors of production, mainly labour and capital, using a particular technological capacity. In similar terms, social capacity may be interpreted as the ability of a community to organize its social capital and other assets in ways that achieve valued economic outcomes.
} 
Based on the foregoing analysis, we specify a social capacity framework that links the incomes of rural people to their ability to organize and use their social capital assets. We propose that the level of income of a rural community depends on the extent to which people in that community are able to organize and use their social capital. Communities in which people are engaged in social structures, relations, and processes that facilitate the use of social capital effectively in income generation are likely to enjoy higher levels of income. Such communities may be considered as being characterized by an income-effective social capacity, which is defined as the effective organization and use of social capital in income generation. On the other hand, communities in which people are involved in social relations and processes that facilitate the use of social capital less effectively in income generation are likely to experience lower income levels. Such communities have less income-effective social capacity.

A crucial aspect of this framework is that the level of a community's income-effective social capacity varies under different modes of social relations and processes. For example, communities with a relatively high level of social capital based in market relations are more likely to have higher incomes than those where the social capital is primarily based in communal relations. This is because such a large proportion of incomes are derived and distributed through market-based mechanisms and productive activities, at least within contemporary, North American conditions. We expect that the other forms of social capital facilitate 
income generation but largely through other types of processes. Communities with high levels of bureaucratic-based social capital are likely to benefit from transfer payments, taxation advantages, and innovative responses to regulations and licensing, for example. Both associative and communal-based social capital can enhance incomes through information transfer, exclusive transactions, and trust-building. Communal-based social capital may increase income through remittances. In each of these cases, however, the predominance of market relations for incomes will remain.

A major feature of a community's social capacity (i.e. its ability to organize and use social capital) is that it facilitates the flow of knowledge and information between its economic agents (individuals, households, and enterprises). People's ability to organize and use social capital influences their level of income because of the exchange of income-related knowledge and information that it facilitates. It is in this respect that all forms of social capital are likely to have their strongest impacts on incomes.

Income-related knowledge includes the type of technical information assumed in current endogenous growth theories (Romer, 1986). While such technical knowledge and information are often acquired by firms through formal research and development, capital investment, and technical training, they are increasingly the result of knowledge spillovers from other firms within the economy (Romer, 1987; 1994). Income-related knowledge is also information that 
employers obtain, which helps them in making appropriate hiring and other operational decisions (Fernandez, Castilla and Moore, 2000). It also includes information that potential employees acquire through personal contacts and social networks, which assists them in job finding (Granovetter, 1995). Our argument is that a community's ability to organize and use social capital can influence its level of income partly because of the flow of income-related information that such social capital use enhances.

\section{EMPIRICAL FORMULATIONS}

The key propositions underlying the framework presented above are (i) that social capacity, defined as the ability of people to organize and use social capital, influences their level of income, and (ii) that this is partly because such social capital use generates and facilitates income-related knowledge and information flow. ${ }^{3}$ Subsidiary to proposition (i) is the assumption that social capital is reflected in four types of social relations: market, bureaucratic, associative, and communal. All these are likely to differentially affect income generation. Implied in the above discussion is the possible endogeneity between income, knowledge flow, and social capital use. On the one hand, social capital use (or social capacity) can influence the level of income through its ability to facilitate information transfer. Conversely, income levels are also expected to 
determine many indicators of some of the types of social capital use being investigated. Moreover, while knowledge and information gained through social interactions can improve income-generating capacity, having a high level of income may give one an advantage of market access and use of vital knowledge and information.

These alternative reactions highlight the need for an empirical model that takes into account the possible endogeneity of income to social capital use and to knowledge access and use. This naturally leads us to specifying two comparable systems of simultaneous equations, one for testing each proposition, using the two-stage-least squares (2SLS) method. For testing the first proposition, which connects income and social capital use, we estimate the following system:

$$
\begin{gathered}
Y_{i}=\pi^{\prime} S_{i}+\beta^{\prime} X_{i}+\varepsilon_{i} \\
S C M_{i}=a_{0}+a_{1} Y_{i}+a_{2} M U_{i}+\varepsilon_{i} \\
S C B_{i}=b_{0}+b_{1} Y_{i}+b_{2} B U_{i}+\varepsilon_{i}
\end{gathered}
$$

where $Y_{i}$ measures the level of income of a given household or community $i$; $S_{i}$ is a vector containing the constant 1 and four variables measuring market-based, bureaucratic-based, associative-based, and communal-based uses or availabilities

\footnotetext{
${ }^{3}$ In this paper we distinguish between the flow and use of knowledge and information. The flow of knowledge and information relates to its exchange and acquisition between agents. The use of knowledge and information relates to how much the acquired knowledge is actually utilized for achieving valued goals.
} 
of social capital at the household or community level; ${ }^{4} X_{i}$ is also a vector of two variables measuring labor force participation and human capital endowment at the household or community level; and $\pi$ and $\beta$ are vectors of the parameters of interest to be estimated.

In equations (2) and (3) the variables $\mathrm{SCM}_{\mathrm{i}}$ and $\mathrm{SCB}_{\mathrm{i}}$ are elements extracted from the vector $\mathrm{S}_{\mathrm{i}}$, and these measure market-based and bureaucratic-based social capital uses or availabilities, respectively; $\mathrm{MU}_{\mathrm{i}}$ and $\mathrm{BU}_{\mathrm{i}}$ are variables measuring some household-level or community-level characteristics, other than income, that influence market-based and bureaucratic-based social capital uses or availabilities, respectively; and the $a \mathrm{~s}$ and $b \mathrm{~s}$ are parameters to be estimated in each corresponding structural equation.

The variables $\mathrm{Y}_{\mathrm{i}}, \mathrm{SCM}_{\mathrm{i}}$, and $\mathrm{SCB}_{\mathrm{i}}$ are the endogenous variables to be jointly determined within the model, while the exogenous variables include all of the elements in the $X_{i}$ vector; the remaining two elements of the $S_{i}$ vector (i.e., the associative-based and communal-based social capital variables); and the variables $\mathrm{MU}_{\mathrm{i}}$ and $\mathrm{BU}_{\mathrm{i}}$, which are defined specifically in the next section. We assume that while all four types of social capital influence the level of income, only marketbased and bureaucratic-based social capital uses and availabilities are influenced

\footnotetext{
${ }^{4}$ As explained in the next section, we estimate all equations at both the household and community levels. When estimating them at the community level, all social capital-related variables are indicated by the availability of social capital and, when estimating them at household level, they are indicated by the use of social capital.
} 
by the level of income. Associative and communal social capital uses and availabilities do not depend on income. We realize that participation in certain associative and communal relationships may entail some financial and income costs; however, such requirements are not likely to be as rigidly enforced as market-based social relationships.

For testing the second proposition, we estimate the relationship between income and knowledge flow and use based on the following set of simultaneous equations:

$$
\begin{gathered}
Y_{i}=\lambda^{\prime} K_{i}+\delta^{\prime} X_{i}+\varepsilon_{i} \\
K F M_{i}=c_{0}+c_{1} Y_{i}+c_{2} M F_{i}+\varepsilon \\
K F B_{i}=d_{0}+d_{1} Y_{i}+d_{2} B F_{i}+\varepsilon
\end{gathered}
$$

where $Y_{i}$ is as defined in equation (1); $K_{i}$ is a vector containing the constant 1 and four variables measuring market-based, bureaucratic-based, associative-based, and communal-based flows and uses of knowledge and information at the household or community level; ${ }^{5} X_{i}$ is a vector of labor force participation and human capital endowment variables, as defined in equation (1); and $\lambda$ and $\delta$ are vectors of the parameters to be estimated. In equations (4) and (5) the variables $\mathrm{KFM}_{\mathrm{i}}$ and $\mathrm{KFB}_{\mathrm{i}}$ are elements taken from the vector $\mathrm{K}_{\mathrm{i}}$, measuring respectively

\footnotetext{
${ }^{5}$ We estimate all equations at both the household and community levels. At the community level, all knowledge-related variables are indicated by the flow or availability of mass communication media assets within the community and, at the household level, they are indicated by the use of such knowledge assets within the household.
} 
market-based and bureaucratic-based knowledge and information flows or uses; $\mathrm{MF}_{\mathrm{i}}$ and $\mathrm{BF}_{\mathrm{i}}$ are variables of some household or community characteristics, other than income, that influence market-based and bureaucratic-based knowledge and information flow or use, respectively; and the $c \mathrm{~s}$ and $d \mathrm{~s}$ are parameters to be estimated in each corresponding equation.

The variables $Y_{i}, K_{F}$, and $\mathrm{KFB}_{\mathrm{i}}$ are the endogenous variables to be determined within the system, while the exogenous variables include all of the elements of the $X_{i}$ vector; the remaining two elements of the $K_{i}$ vector (i.e., the associative-based and communal-based knowledge flow or use variables); and the variables $\mathrm{MF}_{\mathrm{i}}$ and $\mathrm{BF}_{\mathrm{i}}$ which are defined specifically in the next section. For similar reason stated earlier, we assume that while all four types of knowledge and information influence the level of income, only market-based and bureaucraticbased flows and uses are influenced by the level of income. Associative and communal knowledge flows and uses do not require income. Again, we realize that as these types of relations become structured along market and bureaucratic lines, they may require income.

These two models can be consistently estimated given that the equations in each of them satisfy both the order and rank conditions of identification. It can be verified that in each equation the number of excluded exogenous variables is at least equal to the number of endogenous variables included in the right-hand side of the equation, which is the necessary condition for identification (Goldberger, 
1964; Maddala, 1988). In equation (1) the effects of market-based and bureaucraticbased social capital uses or availabilities on income are exactly identified using the variables $\mathrm{MU}_{\mathrm{i}}$ and $\mathrm{BU}_{\mathrm{i}}$ (in equations 2 and 3) as instruments, while in each of these latter equations, the effect of income on market-based or bureaucratic-based social capital use or availability is over-identified by the five exogenous variables within the system that are excluded from each equation. Similarly, in equation (4), the effects of market-based and bureaucratic-based knowledge flows or uses on income are exactly identified using the variables $\mathrm{MF}_{\mathrm{i}}$ and $\mathrm{BF}_{\mathrm{i}}$ (in equations 5 and 6) as instruments. In each of these two equations, the effect of income on marketbased or bureaucratic-based knowledge flow or use is over-identified by the five exogenous variables excluded from each equation.

We expect estimates of the parameters in the vector $\pi$, and those of $a_{1}$ and $b_{2}$ to be positively significant to the extent that the use or availability of social capital has an income-generating effect besides its knowledge and informational benefit, and income itself can influence market-based and bureaucratic-based social capital use and access. Moreover, if our second proposition is true, that is, if social capital affects income creation through its knowledge and informational benefits, then estimates of the parameters in the vector $\lambda$ should be appropriately important. The estimates of the parameters $c_{1}$ and $d_{1}$ should also be important to the extent that income is required for market-based and bureaucratic-based access and use of knowledge and information. Furthermore, if the proposition holds, 
then these social capital variables, when combined with the knowledge and information variables, should not disrupt the significance of the latter. Finally, as noted above, these social capacity variables will be significant only to the extent that social capital availability or use has an income-creating feature in addition to their knowledge and informational benefits. Coleman (1988) has identified other features of social capital (obligations, expectations, trustworthiness, and norms and effective sanctions) that constitute useful capital resources. Thus we cannot rule out the very likely possibility that social capacity might contribute to income generation because of some other elements of social capital use and availability.

\section{DATA AND ESTIMATION}

The models formulated above are estimated using cross-sectional data on household and community social capital from the New Rural Economy (NRE) project of the Canadian Rural Revitalization Foundation (CRRF). This project has identified 32 rural field sites within a strict framework linking them to both global and local conditions (Reimer, 2002b). For the past five years, researchers have been working with people in most of these sites to collect and analyze information relevant to the economic and social conditions of those sites.

We are using data from the project that was collected at two levels: in 20 field sites ${ }^{6}$ and 1995 households within those sites. In the summer of 2000, extensive interviews were conducted with community officials and leaders 
regarding the institutional and historical conditions of the field sites. These interviews provide information about businesses, services (commercial, government, and social), voluntary associations, communication and transportation, and trade within each site. ${ }^{7}$ In the summer of 2001 NRE project researchers conducted randomized, structured interviews in 1995 households in 20 rural field sites. The survey collected information on the demographic and labour force characteristics of the household, use of public and private services, major changes that households faced and their responses to those changes, social cohesion, and informal economic activities.

We test each of the two propositions at both the household and community levels. However, because the available data lack adequate measures of the use of social capital and information at the community level, we employ measures on their availability when testing each proposition at the community level. When testing them at the household level, we employ measures on their use. As pointed out by one anonymous reviewer, we believe that the value of social capital in influencing income or economic development is mainly in its use. Nevertheless, the possible income effect of the availability of social capital still needs to be tested in order to emphatically establish research evidence against those policies that tend to focus exclusively on increasing the availability of social capital.

${ }^{6}$ The field site populations for these 20 sites range from 130 to 6,000 . 
Furthermore, the available data do not allow us to test the second (i.e. knowledge and information) proposition at the household level using an inclusive set of indicators. The only indicator for knowledge and information use, on which we have an adequate measure, is the number of ways the internet is used by each household, involving the different types of social relations. Thus, when testing the second proposition at the household level, we will focus our analysis on the impact of internet use on household income. When testing it on the community level, however, we include a broader set of indicators based on the availability of other kinds of knowledge and information media assets. We realize that by limiting the indicator for information to the Internet (in the household level measures) and mass communication media (for the site level), we are able to capture only a small part of the information component of social capital. This approach still has value, however, since it provides an opportunity for corroboration of the theoretical claims and does so using indicators that are directly available for policy responses.

In estimating equation (1) at the household level, the dependent variable is proxied by the median household income estimated from the NRE household survey data. That survey categorized households according to those earning less than $\$ 20,000$; $\$ 20,000$ to $\$ 29,999 ; \$ 30,000$ to $\$ 39,999 ; \$ 40,000$ to $\$ 59,999 ; \$ 60,000$ to

\footnotetext{
${ }^{7}$ Census Subdivisions were used as initial site boundaries and all enterprises or groups within 30 minutes of the subdivision were included in the inventory.
} 
$\$ 79,999$; and $\$ 80,000$ and over. There are 1995 observations in the sample, representing the number of households that were interviewed. We use the median of each income category, as estimated from the NRE data, as a proxy for the income of households in that category.

On the right-hand side of the equation, the four variables in the $S_{i}$ vector are indicated by their respective indices for social capital use in market, bureaucratic, associative, and communal social relations, as measured in the NRE survey. Such indices measured the aggregate level and number of ways that a household has been involved with market-based, bureaucratic-based, associative-based, and communal-based social relations within the community. Table I provides information regarding the basic characteristics of the indicators for social capital use in the four types of relations. In order to isolate and test for the income effect of social capital use exclusive of the specific contribution of knowledge and information, particularly internet use, the four social capital use variables were adjusted to exclude measures of the number of ways the internet is used involving the different types of relations.

The two variables in the $X_{i}$ vector are indicated by the levels of labour force participation and human capital endowment in the household. Labor force participation is proxied by the number of people employed full-time or part-time in the household, while human capital endowment is indicated by the combined number of years that all individuals within a household have spent in formal 
academic or technical training. The effects of market-based and bureaucratic-based social capital uses on income are identified using the instrumental variables $\mathrm{MU}_{\mathrm{i}}$ and $B U_{i}$ (in equations 2 and 3). $M U_{i}$ is proxied by the density or availability of enterprises and market services within each community, and $\mathrm{BU}_{\mathrm{i}}$ is indicated by the density or availability of bureaucratic services within the community. While the availability of social capital is not equivalent to its use, it is likely to indirectly influence social capital use. Households within communities that have social capital are more likely to use it than those within communities that have no such capital. This possible correlation between social capital use and availability renders either one of these factors an appropriate instrumental variable for identifying the income effect of the other.

In estimating equation (1) at the community level the dependent variable is indicated by the average household income at each community site. In the absence of an alternative proxy for community-level income, the average household income was used for the community, which is analogous to using the level of per capita income for a country. We have derived this by calculating the average of the median household incomes across all household categories within each community.

For the independent variables we use as proxies the summary indicators for social capital available in the community for the four types of relations. Information regarding the basic characteristics of these indicators is presented in 
Table II. Such indices measure the availability of social capital at the community level, and are represented in the NRE survey as the densities of enterprises and market services per 100 people, bureaucratic services per 100 people, associative services per 100 people, and communal services per 100 people. In order to isolate and test for the income effect of social capital availability exclusive of the specific contribution of knowledge and information, the indices were adjusted to exclude measures of the number of mass communication media assets and services available at each site involving the different types of relations. Labour force participation and human capital endowment at the community level are indicated, respectively, by the number of paid workers and the number of people with a university education and or technical training in the community.

The effects of market-based and bureaucratic-based social capital availabilities on income are identified using the instrumental variables $M U_{i}$ and $\mathrm{BU}_{\mathrm{i}}$ (in equations 2 and 3). At the community level, however, these variables are proxied respectively by the average household market-based social capital use and average household bureaucratic-based social capital use at each community site. These are derived by calculating the average indices of household market-based and bureaucratic-based social capital uses across all households in each community. Similar to our previous argument, the extent of the use of social capital by households is likely to indirectly influence social capital availability within a community, since households which use such capital are more likely to 
advocate for its availability in their communities than those which do not use it. Thus the use of social capital at the community level is a proper instrument for identifying the effect of its availability on income.

As noted earlier, we test the second proposition also at both the household and community levels. In estimating equation 4 at the household level, the dependent variable is again proxied by the median household income. For the independent variables we needed proxies for the use of knowledge and information within market, bureaucratic, associative, and communal social relations. The only available proxies for knowledge and information use were the indices on the use of the Internet, as reported in Table I in the form of marketbased use, bureaucratic-based use, associative-based use, and communal-based use. The two variables, in the $X_{i}$ vector, on labour force participation and human capital endowment are proxied respectively by the number of people employed full-time or part-time in the household, and the combined number of years that all individuals within a household have spent in formal academic or technical training. The inclusion of human capital endowment with internet use in this equation is likely to improve our test of the second proposition.

The effects of market-based and bureaucratic-based knowledge and information uses on income are identified using the instrumental variables $\mathrm{MF}_{\mathrm{i}}$ and $\mathrm{BF}_{\mathrm{i}}$ (in equations 5 and 6 ). These variables are indicated respectively by the number of market-based mass communication services and the number of 
bureaucratic communication services available in each community. For the same reason advanced earlier, the availabilities of such knowledge and information services within a community can serve as appropriate instruments for identifying the effects of internet use on income at the household level. The number of mass communication media services (e.g. TVs and newspapers) in a community is likely to affect the use of the internet by households.

While the level of rural internet use was found to be relatively low (about $59 \%$ of the households interviewed reported zero internet use), internet use in general can serve as a key indicator for knowledge and information use. Although electronic networks and virtual communities created through the use of the internet are different from real communities, such networks can play a role in strengthening real communities if they are used to augment social networks that are already in place (Wellman, 1992). As Scott (1997) has pointed out, in addition to their obvious benefits as text-based information systems, electronic networks "can serve as public spaces for informal citizen-to-citizen interaction, they can support rational dialogue and, in some cases, deliberation, and they can promote the social connectedness, trust, and cooperation that constitute social capital". Since knowledge and information naturally pass through social relationships, internet use can serve as an indicator for the exchange of the knowledge and information that travel through such relationships. In our own survey, people in the various rural communities indicated how the internet has improved their 
access to government information and had a positive impact on their relationships with others in the communities. Moreover, as indicated above, the combination of human capital endowment with internet use in the model is likely to augment its explanatory power.

For estimating equation (4) at the community level, the dependent variable is indicated by the average household income at each community site. Again, this was derived by calculating the average levels of household income across all households in each community site. For the independent variables we use as proxies the total of communication services available in each community for market-based, bureaucratic-based, and associative-based relations. Such variables have been defined in the NRE survey as the total of cable TVs, public access terminals, local newspapers, regional newspapers, national newspapers, community newsletters, local radio stations, and the number of available radio stations at a site. To these we have added a comparable variable for communalbased relations, that is, the total of community-integration events in each site. This variable measures the number of events such as festivals, community picnics, or celebrations that bring the community people together on a regular basis. While such events are not communication services per se, they often provide the forums through which people interact and thus exchange vital knowledge and information. Indicators for these four variables are contained in Table II, which were used as proxies for the knowledge and information variables in equation (4). 
Labour force participation and human capital endowment at the community level are indicated, respectively, by the number of paid workers and the number of people with a university education and or technical training in the community. The effects of the availabilities of market-based and bureaucraticbased mass communication media services on income are identified using the instrumental variables $\mathrm{MF}_{\mathrm{i}}$ and $\mathrm{BF}_{\mathrm{i}}$ (in equations 5 and 6). At the community level, these variables are proxied respectively by the average household market-based internet use and average bureaucratic-based internet use at each community site. This was derived by calculating the average indices of household market-based and bureaucratic-based internet uses across all households in each community site.

\section{EMPIRICAL RESULTS}

The estimation results for the two systems of equations are presented in Table III and Table IV. Column (A) in Table III contains the estimations of the first set of equations (1) to (3) at the household level, while Column (B) contains the estimations of these same equations at the community level. In each of the column cells, the standardized regression coefficients are reported on top without parenthesis. Numbers reported in parenthesis are the standard errors.

Results from estimating equation (1), in column (A), indicate a statistically significant relationship between household income and social capital use in all types of relations. The individual regression coefficients on the four social capital 
use variables are all significant, even though that on the bureaucratic social capital use variable is negative. Given the substantial sizes of these coefficients (e.g. $\$ 11,695$ and $\$ 4,063$ for market-based and associative-based social capital uses, respectively), we may conclude that increasing the level of household involvement in any type of social relations has an important income effect. Such income effects are likely to be even more economically significant and pronounced for households that are in lower income categories. In the case of bureaucratic-based social capital use, the results suggest that raising household involvement in bureaucratic relations has a substantial income-reducing effect, and decreasing household involvement has a significant income-enhancing effect. Such may be the case when rural households' dependence on bureaucratic relations and sources of income is so high that there is less time for them to get involved in other types of relations, and their exclusive bureaucratic reliance does not itself generate significant income.

Results from estimating equations (2) and (3) indicate that household income has a positive effect on market-based social capital use and a negative impact on bureaucratic social capital use (see column A, Table III). The latter result suggests the possibility that rural households with higher income are less dependent on government bureaucratic sources of income. The analytical significance of these results appears to be strong in the case of market-based social capital use, but weak in the case of bureaucratic use. Based on the sizes of the 
coefficient estimates on household income, a dollar increase in income is likely to raise a household's involvement in market-based relations by almost an entire one way of involvement (i.e. 0.789). However, an extra dollar of income reduces bureaucratic social capital use by only 0.06 way of involvement. In the context of our sample, in which the estimated means of market and bureaucratic social capital uses are, respectively, 9.77 and 7.90 (see Table I), such effects of income are economically significant in the case of market-based use but weak in the case of bureaucratic use.

The results also show that the availabilities of market-based and bureaucratic-based types of social capital within a community have positive effects on their uses within the household, as indicated by the significance of the coefficients on these availability variables (see column A, Table III). While these are statistically significant, one should be cautious in attaching any economic importance to them. Based on these coefficient estimates, the availability of one extra market-based social capital organization in a community tends to increase people's use of such capital by only 0.07 way of involvement, while one extra bureaucratic-based social capital organization tends to raise its use by only 0.11 way.

Column (B) provides the results from estimating the same three equations at the community level. The results from estimating equation (1) indicate that the relationship between income and the mere availability of social capital is at least 
not strong at the community level. The small sample size (20 observations) used in estimating the relationship may have contributed to such a result. The individual regression coefficients on the four social capital availability factors are mostly statistically insignificant, with the exception of the market-based social capital variable which is significant only at the ten percent level. The coefficients on labor force participation and human capital endowment are positively significant. The coefficient of determination, R-square, is 0.558 , suggesting that about $55 \%$ of variation in household income has been explained by the six variables used in the model. It should be noted that while the coefficient estimates on the social capital availability factors are statistically insignificant, their substantial sizes point to some economic importance.

Results from estimating equations (2) and (3) at the community level indicate that the level of a community's income has at least a weak positive effect on the amount of its market-based social capital stock; but it has no impact on the amount of its bureaucratic social capital stock. Based on the coefficient estimates, an additional dollar of community income is likely to raise market-based social capital by 0.413 and decrease bureaucratic social capital by 0.075 . In the context of our sample (see Table II), these may be considered economically significant estimates. The results also suggest that a community's use of market-based social capital has a positive effect on the availability of such capital within the community. But the use of bureaucratic-based social capital appears to have no 
similar effect, as indicated by the significance of the coefficients on these use variables (see column B, Table III).

Column (A) in Table IV provides the results from estimating equations (4) at the household level. These show a statistically significant relationship between household income and the use of the internet in all four types of relations. The individual regression coefficients on the four internet use variables are all positively significant at the five percent level, and those on labor force participation and human capital endowment are also positively significant, even though the former is significant only at the ten percent level. The coefficient of determination is 0.648 , suggesting that about $65 \%$ of variation in household income has been explained by internet use, employment, and human capital endowment. Our previous analysis of the income effects of social capital uses also applies here. Given the large sizes of the coefficient estimates on the four types of internet use, we may conclude that increasing any type of internet use by the household has an important income effect.

Results from estimating equations (5) and (6) at the household level, also reported in column (A), Table IV, indicate that household income has a positive effect on market-based internet use but no significant impact on bureaucratic internet use. That household income has no significant effect on rural bureaucratic use of the internet may be explained by the speculation that such internet use is largely underwritten by public finance. In terms of our sample, however, it could 
be argued that household income has economically substantial impact on bureaucratic-based as well as market-based internet use. While the coefficient estimate on income, in the case of the former (i.e. 0.112), is found to be statistically insignificant, it is substantial given that the average number of ways the internet is used involving bureaucratic relations by households is only 0.53 (see Table I). Thus the fact that a dollar increase in household income might raise such use by 0.112 is analytically significant. The results also show that the availabilities of market-based and bureaucratic-based mass communication media (e.g. TV and newspapers) within a community have negative effects on internet uses by the household, as indicated by the significance of the coefficients on these availability variables (column A, Table IV).

Column (B) in Table IV contains the results from estimating the three equations at the community level. The results from estimating equation (4) indicate that the relationship between income and the availability of mass communication media assets in all four types of relations is insignificant at the community level. While the coefficient of determination for this equation is relatively high, about 0.62 , none of the individual coefficients on the four variables have been found to be significant. This suggests that labor force participation and human capital endowment may have been the main factors explaining this high coefficient of determination. While the estimated coefficients on the mass 
communication media factors are statistically insignificant, their substantial sizes seem to indicate some economic significance.

Results from estimating equations (5) and (6) at the community level indicate that a dollar increase in a community's income is likely to raise its stock of market-based mass communication media assets by 0.216 . This is an economically important impact, especially for those rural communities that have only one or two communication assets. A similar income increase is likely to reduce the availability of bureaucratic-based communication media by 0.247 . While this result has been found to be statistically insignificant, in the context of our sample in which the average number and maximum number of community media assets are only 2.68 and 3, respectively, such an effect of income is substantial. Similarly, in the context of our sample, market-based use of the internet is likely to substantially increase the availability of other market-based non-internet communication assets, and bureaucratic-based use is likely to reduce the availability of bureaucratic-based communication assets. Based on the statistical evidence, however, such effects have been found to be insignificant (see column B, Table IV).

In order to complete the testing of the second proposition, we have reintroduced and combined the social capital use variables, from equation (1), with the variables on knowledge and information use, labor force participation and human capital endowment, from Equation (4). The purpose for formulating 
such a complete model was to determine whether these social capital use variables would affect the significance of the knowledge variables once introduced, and to find out if such social capital use has another income-generating channel besides knowledge and information flow. According to the theory (Kvanli, 1988), if the computed partial $\mathrm{F}$ value turns out to be statistically significant, then the previously excluded variables (in this case, the social capital use variables) should be considered as contributing significantly to income generation. Such a finding would suggest that social capital affects income not only through its facilitation of information flow. However, a contrary finding would strengthen the case for knowledge and information.

We have estimated the complete model at the household level because, as our results above show, the relationship between income and the availability of social capital and knowledge and information appears to be at least statistically insignificant at the community level. Thus the dependent variable is the household income, and the independent variables are the four variables on social capital use; the four variables on internet use; and the two variables on labor force participation and human capital endowment. The coefficients on all of the internet use variables have remained significant at the five percent level, thus indicating that the reintroduction of the social capital use variables has not affected their significance. 
The R-square from the complete regression was found to be 0.73 . Using the R-square from the reduced model involving only internet use, which is 0.65 , we calculated the partial F-statistic as 147. Theoretically, the partial F-statistic measures the extent to which inclusion of previously excluded variables has impacted the value of the R-square. The partial F value was found to be significant at the ten percent level, suggesting that social capital use has other incomeenhancing channels besides internet use. Thus this confirms our proposition that social capacity affects income partly because it facilitates the flow of incomerelated knowledge and information.

\section{CONCLUSIONS AND POLICY IMPLICATIONS}

In this research we have undertaken the task of showing how social capacity, defined in terms of the availability and effective use of social capital, impacts upon income generation in rural Canada. Our objective was also to determine whether and to what extent overall social capacity, or social capital availability and use, generates income because of the facilitating role of knowledge and information flow. Thus the key research propositions formulated were (i) that social capital availability and use do affect the level of income, and (ii) that this is partially because such a capacity facilitates the flow (availability and use) of income-related knowledge and information.

Using a set of empirical formulations based on two systems of simultaneous equations, these research propositions were tested using data on household and 
community social capital from the New Rural Economy (NRE) project of the Canadian Rural Revitalization Foundation (CRRF). The main conclusions and policy implications from this analysis are summarized as follows:

1. It has been found that overall there is an important relationship between household social capital use and household income. Based on the reported regression coefficients on variables included in the estimation, it can be concluded that all types of social capital use are positive determinants of household income. Only bureaucratic-based use is negatively related to income. Household income has also been found to have a positive impact on market-based social capital use and a negative effect on bureaucratic social capital use. This suggests that as incomes of rural households rise, their dependence on government bureaucratic sources of income is likely to decline.

2. These results confirm the value of considering social capital in terms of the types of relations which underlie it. Social capital is built on at least four different types of social relations, and each of them involves different processes and effects. As our data show, not all types are positively related to incomes. Much more is required to identify the conditions under which the four types, for example, reinforce one another, or where they conflict.

3. The paucity of the available data did not allow us to conduct a test on the relationship between social capital use and income at the community level. 
However, we were able to test a similar relationship between income and the availability of social capital at the community level. The results indicate that while the availability of neither type of social capital has a significant effect on income, the level of a community's income has a positive impact on the amount of its market-based social capital stock; but it has a negative effect on the amount of its bureaucratic social capital stock.

4. The analysis reveals an important gap between the availability of social capital and its use. This affirms the value of research investigations into the conditions under which availability is transformed into use, and cautions those policies that focus on increasing the availability of social capital alone.

5. We have also found that there is an important relationship between household income and knowledge and information use, as measured by internet use. Based on the reported regression coefficients on variables included in the estimation, we have found that internet uses in all four types of social relations are positive determinants of household income. Moreover, household income has been found to have a positive economic impact on market-based and bureaucratic-based internet uses, although the latter effect turned out to be statistically insignificant. This result may be a confirmation of the claim that in rural Canada bureaucratic use of the internet is largely underwritten by government support. 
6. Again, the lack of appropriate data prevented us from testing the relationship between knowledge and information use and income at the community level. We were able to test a similar relationship between income and the availability of other kinds of knowledge and information media assets; however, while results from this test show no significant impact of the availability of knowledge and information media on income, the latter has been found to have a positive effect on the availability of market-based communication media. Finally, we have found evidence that the flow and use of knowledge and information, at least in the form of internet use, can improve the income-generating capacity of other forms of social capital. The social capacity for income generation can be improved through the exchange of information using the internet. This was confirmed at least on the household level for rural Canada, using the available data. 


\section{REFERNCES}

Amin, A., 1994. The Potential for Turning Informal Economies into Marshalian Industrial Districts. In: United Nations (Ed.), Technological Dynamism in Industrial Districts: An Alternative Approach to Industrialization in Developing Countries. United Nations, Geneva.

Barr, A., 2000. Social Capital and Technical Information Flows in the Ghanaian Manufacturing Sector. Oxford Economic Papers 52, 539-59.

Barro, R., Sala-i-Martin, X., 1995. Economic Growth. McGraw-Hill, New York.

Bebbington, A., Perreault, T., 1999. Social capital, development, and access to resources in highland Ecuador. Economic Geography 75 (2), 395-418.

Coleman, J., 1988. Social Capital in the Creation of Human Capital. American Journal of Sociology 94 (Supp.), 95-120. , 1994. The rational choice perspective in economic sociology. In:

Smelser, N. J., Swedberg, R. (Eds.), The Handbook of Economic Sociology. Princeton University Press, New Jersey.

Coleman, J., Katz, E., Menzel, M., 1966. Medical Innovation: A Diffusion Study. Bobbs-Merrill, New York, cited in Barr, 2000.

Datt, G., Ravallion, M., 1998. Why Have Some Indian States Done Better than Others at Reducing Rural Poverty?. Economica 65, 17-38. 
Fernandez, R. M., Castilla, E. J., Moore, P., 2000. Social Capital at Work: Networks and Employment at a Phone Center. American Journal of Sociology 105(5), 1288-1356.

Fiske, A. P., 1991. Structures of Social Life: The Four Elementary Forms of Human Relations: Communal Sharing, Authority Ranking, Equality Matching, and Market Pricing. The Free Press, Toronto, cited in Reimer, W., 2002.

Goldberger, A. S., 1964. Econometric Theory. Wiley, New York.

Granovetter, M. S., 1973. The Strength of Weak Ties. American Journal of Sociology 78, 1360-80. 1995. Getting a Job: A Study of Contacts and Careers. University of Chicago Press, Chicago.

Helliwell, J., Putnam, R., 1995. Economic Growth and Social Capital in Italy. Eastern Economic Journal 21(3), 295-307.

Jacques, P., 2001. Use of the Internet by Middle-Market Consumers. LIMRA's Market Facts, Spring, 20-21.

Knack, S., Keefer, P., 1997. Does Social Capital Have an Economic Payoff? A Cross-Country Investigation. Quarterly Journal of Economics 62(4), 1251-88.

Kvanli, A. H., 1988. Statistics: A Computer Integrated Approach. West Publishing Company, Minnesota.

Maddala, G. S., 1988. Introduction to Econometrics. Macmillan Publishing Company, New York. 
Putnam, R., 1993. Making Democracy Work: Civic Traditions in Modern Italy. Princeton University Press, Princeton. 1995. Bowling alone: America's declining social capital. Journal of Democracy 6(1).

Reimer, W., 2002a. Understanding Social Capital: Its Nature and Manifestations in Rural Canada (A paper prepared for presentation at the CSAA Annual Conference, Toronto).

Reimer, B., 2002b. A sample frame for rural Canada: design and evaluation. Regional Studies 36(8), 845-859.

Romer, P. M., 1986. Increasing Returns and Long Run Growth. Journal of Political Economy 94, 1003-37. 1987. Growth Based on Increasing Returns Due to Specialization. American Economic Review 77(2), 56-62. 1994. The Origins of Endogenous Growth. Journal of Economic Perspectives 8, 3-22.

Sandefur, R. L., Laumann, E. O., 1998. A paradigm for social capital. Rationality and Society 10(4), 481-501.

Sandefur, R. L., Laumann, E. O., et al., 1999. The changing value of social capital in an expanding social system: Lawyers in the Chicago Bar, 1975 and 1995. In: Roger, A. J., Gabbay, S. M. (Eds.), Corporate Social Capital and Liability. Kluwer Academic Publishers, Norwell. 
Scott, J., 1997. Civic Networks: Building Community on the Net (a Paper a prepared for the Kettering Foundation: Available at http://www.west.net/ insight/london/networks.htm, September 2, 2002).

Stabler, Jack C., M.R. Olfert, and Murray Fulton, 1992. The Changing Role of Rural Communities in an Urbanizing World: Saskatchewan 1961-1990. Canadian Plains Research Center, University of Regina.

Temple, J., 1998. Initial Conditions, Social Capital, and Growth in Africa. Journal of African Economics 7(3), 309-67.

Temple, J., Johnson, P., 1998. Social capability and Economic Growth. The Quarterly Journal of Economics, August, 965-990.

Wellman, B., 1992. Which types of ties and networks provide what kinds of social support? Advances in Group Processes 9, 207-235.

Whiteley, P. F., 2000. Economic Growth and Social Capital. Political Studies $48,443-466$. 
Table I: Indicators of the Use of Social Capital - 4 Types of Relations

\begin{tabular}{|c|c|c|c|c|c|}
\hline & $\mathrm{N}$ & Min & Max & Mean & Std Deviation \\
\hline \multicolumn{6}{|l|}{ Market-based Use } \\
\hline $\begin{array}{l}\text { access to market relations - employ someone or own } \\
\text { business }\end{array}$ & 1995 & 0 & 14 & 2.12 & 2.01 \\
\hline $\begin{array}{l}\text { use internet for market relations (e.g. employment, on- } \\
\text { line purchases) }\end{array}$ & 1995 & 0 & 4 & 0.47 & 0.88 \\
\hline $\begin{array}{l}\text { market public services used (e.g. gas, bank, financial } \\
\text { advisor) }\end{array}$ & 1995 & 0 & 12 & 5.65 & 1.22 \\
\hline $\begin{array}{l}\text { number of market participation groups (e.g. } \\
\text { employment group) }\end{array}$ & 1995 & 0 & 4 & 0.08 & 0.31 \\
\hline $\begin{array}{l}\text { income from market sources (e.g. wages, self- } \\
\text { employment, farm) }\end{array}$ & 1995 & 0 & 4 & 1.40 & 0.98 \\
\hline total market supports & 1995 & 0 & 4 & 0.19 & 0.49 \\
\hline summary indicator for market-based use & 1995 & 0 & 27 & 9.77 & 3.79 \\
\hline \multicolumn{6}{|l|}{ Bureaucratic-based Use } \\
\hline $\begin{array}{l}\text { use internet for bureaucratic relations (e.g. } \\
\text { government info.) }\end{array}$ & 1995 & 0 & 6 & 0.53 & 1.09 \\
\hline $\begin{array}{l}\text { bureaucratic public services used (e.g. hospital, legal, } \\
\text { library) }\end{array}$ & 1995 & 0 & 14 & 5.37 & 2.16 \\
\hline $\begin{array}{l}\text { number of bureaucratic actions taken (e.g. letter to } \\
\text { gov't rep.) }\end{array}$ & 1995 & 0 & 1 & 0.13 & 0.34 \\
\hline $\begin{array}{l}\text { income from bureaucratic sources (e.g. gov't pension, } \\
\text { EI, welfare) }\end{array}$ & 1995 & 0 & 7 & 1.38 & 1.15 \\
\hline total bureaucratic supports & 1995 & 0 & 7 & 0.49 & 0.80 \\
\hline summary indicator for bureaucratic-based use & 1995 & 0 & 21 & 7.90 & 3.07 \\
\hline \multicolumn{6}{|l|}{ Associative-based Use } \\
\hline $\begin{array}{l}\text { use internet for associative relations (e.g. volunteer } \\
\text { work) }\end{array}$ & 1995 & 0 & 1 & 0.06 & 0.24 \\
\hline associative public services used (e.g. meal programs) & 1995 & 0 & 2 & 0.29 & 0.46 \\
\hline $\begin{array}{l}\text { number of associative participation groups (e.g. } \\
\text { recreation, environment, religious, service) }\end{array}$ & 1995 & 0 & 21 & 2.24 & 2.88 \\
\hline $\begin{array}{l}\text { number of associative actions taken (e.g. give money, } \\
\text { sign petition) }\end{array}$ & 1995 & 0 & 5 & 1.37 & 1.16 \\
\hline total associative supports & 1995 & 0 & 4 & 0.12 & 0.38 \\
\hline summary indicator for associative-based use & 1995 & 0 & 26 & 4.07 & 3.66 \\
\hline \multicolumn{6}{|l|}{ Communal-based Use } \\
\hline $\begin{array}{l}\text { use internet for communal relations (e.g. contacting } \\
\text { family, friends) }\end{array}$ & 1995 & 0 & 2 & 0.50 & 0.73 \\
\hline $\begin{array}{l}\text { total types of sharing from family and friends (e.g. } \\
\text { food, auto repair, home care) }\end{array}$ & 1995 & 0 & 11 & 2.34 & 1.93 \\
\hline total communal supports & 1995 & 0 & 8 & 1.00 & 1.47 \\
\hline summary indicator for communal-based use & 1995 & 0 & 15 & 3.84 & 2.67 \\
\hline Total of 4 types of use & 1995 & 4 & 59 & 25.58 & 9.03 \\
\hline
\end{tabular}


Table II: Indicators of the Availability of Social Capital - 4 Types of Relations

\begin{tabular}{|c|c|c|c|c|c|}
\hline & $\mathrm{N}$ & Min & Max & Mean & Std Deviation \\
\hline \multicolumn{6}{|l|}{ Market Relations } \\
\hline number of businesses within 30 minutes of site & 17 & 4 & 350 & 77.53 & 104.09 \\
\hline $\begin{array}{l}\text { no of market-based services within } 30 \text { minutes of site } \\
\text { (e.g. banks, ATM machines, Insurance office) }\end{array}$ & 19 & 0 & 5 & 1.74 & 1.76 \\
\hline $\begin{array}{l}\text { no of market communication services (e.g. cable, } \\
\text { internet, national newspaper) }\end{array}$ & 19 & 1 & 8 & 6.00 & 1.73 \\
\hline $\begin{array}{l}\text { commercial shopping code from iwg survey (Stabler, } \\
\text { et.al., 1992) }\end{array}$ & 19 & 0 & 3 & 1.16 & 0.90 \\
\hline total of business and market services for site & 19 & 5 & 359 & 78.26 & 102.48 \\
\hline density of enterprises and market services & 19 & .30 & 30.07 & 7.09 & 6.68 \\
\hline \multicolumn{6}{|l|}{ Bureaucratic Relations } \\
\hline $\begin{array}{l}\text { no of bureaucratic services within } 30 \text { minutes of site (e.g. } \\
\text { schools, hospital, Employment Office) }\end{array}$ & 19 & 0 & 32 & 9.37 & 8.82 \\
\hline $\begin{array}{l}\text { no of bureaucratic communication services (e.g. } \\
\text { internet, national newspaper) }\end{array}$ & 19 & 1 & 3 & 2.68 & 0.75 \\
\hline $\begin{array}{l}\text { no of bureaucratic access services within } 30 \text { minutes (e.g. } \\
\text { school, hospital, employment office) }\end{array}$ & 19 & 2 & 35 & 12.05 & 9.04 \\
\hline density of bureaucratic services & 19 & .10 & 7.01 & 1.93 & 2.09 \\
\hline \multicolumn{6}{|l|}{ Associative Relations } \\
\hline $\begin{array}{l}\text { no of associative-based services within } 30 \text { minutes of site } \\
\text { (e.g. food bank, rink, community center) }\end{array}$ & 19 & 0 & 18 & 6.68 & 5.20 \\
\hline $\begin{array}{l}\text { no of associative communication services (e.g. } \\
\text { community newspaper, local radio station) }\end{array}$ & 19 & 1 & 11 & 7.58 & 2.55 \\
\hline no of associative access services within 30 minutes & 19 & 3 & 28 & 14.26 & 6.78 \\
\hline density of associative services & 19 & .19 & 12.74 & 2.52 & 3.02 \\
\hline \multicolumn{6}{|l|}{ Communal-based Relations } \\
\hline average of number of people in census families & 20 & 3 & 4 & 3.07 & 0.32 \\
\hline $\begin{array}{l}\text { no of communal-based services in site (e.g. daycare, } \\
\text { retirement home) }\end{array}$ & 19 & 4 & 12 & 5.63 & 1.98 \\
\hline index of communal relations - basic & 20 & 4 & 14.9 & 8.40 & 2.13 \\
\hline density of communal index & 20 & 70.83 & 97.56 & 88.85 & 6.67 \\
\hline Density of 4 types of social capital & 20 & .10 & 33.2 & 12.40 & 10.40 \\
\hline
\end{tabular}


Table III: Testing relationships between income, and social capital use and availability

\begin{tabular}{|c|c|c|}
\hline & $\begin{array}{c}\text { (A) } \\
\text { Proposition I at } \\
\text { Household Level }\end{array}$ & $\begin{array}{c}\text { (B) } \\
\text { Proposition I at } \\
\text { Community Level }\end{array}$ \\
\hline & \multicolumn{2}{|c|}{ Equation 1} \\
\hline (Constant) & $\begin{array}{l}125085 \\
(30451)\end{array}$ & $\begin{array}{l}-35187 \\
(349915)\end{array}$ \\
\hline Market-based social capital use or availability & $\begin{array}{l}11695 \\
(5891) \\
\end{array}$ & $\begin{array}{l}9278^{*} \\
(5609)\end{array}$ \\
\hline Communal-based social capital use or availability & $\begin{array}{c}595^{*} \\
(347)\end{array}$ & $\begin{array}{l}11211^{* *} \\
(70073)\end{array}$ \\
\hline Associative social capital use or availability & $\begin{array}{l}4063 \\
(962) \\
\end{array}$ & $\begin{array}{l}-45168^{* *} \\
(212697) \\
\end{array}$ \\
\hline Bureaucratic-based social capital use or availability & $\begin{array}{l}-7253 \\
(2586) \\
\end{array}$ & $\begin{array}{l}56465^{* *} \\
(268370)\end{array}$ \\
\hline Labor force participation & $\begin{array}{l}31202 \\
(12808)\end{array}$ & $\begin{array}{l}38 \\
(15)\end{array}$ \\
\hline Human capital endowment & $\begin{array}{l}5853 \\
(1142) \\
\end{array}$ & $\begin{array}{l}72 \\
(33) \\
\end{array}$ \\
\hline \multirow[t]{2}{*}{ R Squares } & 0.69 & 0.55 \\
\hline & \multicolumn{2}{|c|}{ Equation 2} \\
\hline (Constant) & $\begin{array}{l}.921 \\
(.362)\end{array}$ & $\begin{array}{l}6 \\
(8)\end{array}$ \\
\hline Household or community-level income & $\begin{array}{l}.789^{*} \\
(.457) \\
\end{array}$ & $\begin{array}{l}.413^{*} \\
(.250) \\
\end{array}$ \\
\hline Market-based social capital use or availability & $\begin{array}{l}.068 \\
(.018) \\
\end{array}$ & $\begin{array}{c}.565^{*} \\
.341 \\
\end{array}$ \\
\hline \multirow[t]{2}{*}{ R Squares } & 0.51 & 0.05 \\
\hline & \multicolumn{2}{|c|}{ Equation 3} \\
\hline (Constant) & $\begin{array}{l}6 \\
(.256) \\
\end{array}$ & $\begin{array}{l}.543 \\
(4.259) \\
\end{array}$ \\
\hline Household or community-level income & $\begin{array}{l}-.058^{*} \\
(.021)\end{array}$ & $\begin{array}{l}-.075^{\star *} \\
(.137)\end{array}$ \\
\hline Bureaucratic-based social capital use or availability & $\begin{array}{l}116 \\
(.039) \\
\end{array}$ & $\begin{array}{l}.785^{\star *} \\
(.536)\end{array}$ \\
\hline R Squares & 0.02 & 0.18 \\
\hline
\end{tabular}

Notes: Standardized regression coefficients are reported on top without parenthesis. Standard errors are reported in parenthesis. Coefficients without asterisk are significant at the five percent level. Those with a single asterisk are significant at the ten percent level, while those with a double asterisk are considered as insignificant. Estimates in column (A) are for household income and the various types of social capital uses as predictors, while those in column (B) are for community income and the various types of social capital availabilities as predictors. 
Table IV: Testing relationships between income, and knowledge flow and use

\begin{tabular}{|c|c|c|}
\hline & $\begin{array}{l}\text { (A) } \\
\text { Proposition II at } \\
\text { Household Level }\end{array}$ & $\begin{array}{c}\text { (B) } \\
\text { Proposition II at } \\
\text { Community Level }\end{array}$ \\
\hline & \multicolumn{2}{|c|}{ Equation 4} \\
\hline (Constant) & $\begin{array}{l}30107 \\
(12807)\end{array}$ & $\begin{array}{l}6082154 \\
(698205224)\end{array}$ \\
\hline $\begin{array}{l}\text { Market-based use of Internet or the number of } \\
\text { market communication services }\end{array}$ & $\begin{array}{l}80818 \\
(40525)\end{array}$ & $\begin{array}{l}16893^{* *} \\
(1793673) \\
\end{array}$ \\
\hline $\begin{array}{l}\text { Communal-based use of Internet or the number. of } \\
\text { community-integration events }\end{array}$ & $\begin{array}{l}898 \\
(411)\end{array}$ & $\begin{array}{l}-560738 * * \\
(64885389)\end{array}$ \\
\hline $\begin{array}{l}\text { Associative use of Internet or the number. of } \\
\text { associative communication services }\end{array}$ & $\begin{array}{l}11672 \\
(5778) \\
\end{array}$ & $\begin{array}{l}378759 * * \\
(44283778) \\
\end{array}$ \\
\hline $\begin{array}{l}\text { Bureaucratic-based use of Internet or the number } \\
\text { of bureaucratic communication services }\end{array}$ & $\begin{array}{l}76103 \\
(36395)\end{array}$ & $\begin{array}{l}-3014853^{* *} \\
(347602512)\end{array}$ \\
\hline Labor force participation & $\begin{array}{l}1625^{*} \\
(959)\end{array}$ & $\begin{array}{l}1263 \\
(561)\end{array}$ \\
\hline Human capital endowment & $\begin{array}{l}7925 \\
(3873)\end{array}$ & $\begin{array}{l}6937 \\
(3219)\end{array}$ \\
\hline \multirow[t]{2}{*}{ R Squares } & 0.65 & 0.62 \\
\hline & \multicolumn{2}{|c|}{ Equation 5} \\
\hline (Constant) & $\begin{array}{l}-1.201 \\
(.120) \\
\end{array}$ & $\begin{array}{l}7 \\
(5)\end{array}$ \\
\hline Household or community-level income & $\begin{array}{l}.457 \\
(.200) \\
\end{array}$ & $\begin{array}{l}.216^{*} \\
(.122) \\
\end{array}$ \\
\hline $\begin{array}{l}\text { Market-based use of the Internet or number of } \\
\text { market communication services }\end{array}$ & $\begin{array}{l}-.518 \\
(.225)\end{array}$ & $\begin{array}{l}3^{* *} \\
(5)\end{array}$ \\
\hline \multirow[t]{2}{*}{ R Squares } & 0.28 & 0.27 \\
\hline & \multicolumn{2}{|c|}{ Equation 6} \\
\hline (Constant) & $\begin{array}{l}-1.106 \\
(.165) \\
\end{array}$ & $\begin{array}{l}2 \\
(1.343) \\
\end{array}$ \\
\hline Household or community-level income & $\begin{array}{l}.112^{* *} \\
(.456) \\
\end{array}$ & $\begin{array}{l}-.247^{* *} \\
(.781)\end{array}$ \\
\hline $\begin{array}{l}\text { Bureaucratic-based use of the Internet or number } \\
\text { of bureaucratic communication services }\end{array}$ & $\begin{array}{l}-.087^{*} \\
(.050) \\
\end{array}$ & $\begin{array}{l}-.186^{* *} \\
(1.460)\end{array}$ \\
\hline R Squares & 0.29 & 0.05 \\
\hline
\end{tabular}

Notes: Standardized regression coefficients are reported on top without parenthesis. Standard errors are reported in parenthesis. Coefficients without asterisk are significant at the five percent level. Those with a single asterisk are significant at the ten percent level, while those with a double asterisk are considered as insignificant. Estimates in column (A) are for household income and the various types of internet uses as predictors, while those in column (B) are for community income and the various types of communication media assets as predictors. 